\title{
A Study of the Bereavement of the Mother in Siegfried Sassoon's Poem "The Hero" and Walt Whitman's Poem "Come Up from the Fields, Father"
}

\author{
Dr. Kanar Asaad Adham \\ Ph.D. English literature, Dept. of English- School of Language, \\ University of Sulaimani, Sulaimani, Iraq
}

\begin{abstract}
War poetry is the literary achievement of those poets who actually participated in war, as soldierpoets, or witnessed the horrors and the catastrophes of war in one way or another. They share the same concern about battlefields and trenches as a main core and source of inspiration of their poetry. Modes of writings about war were practiced by those poets; however, they hardly mentioned the effect of war on the soldiers' families in their poetry. This paper turns attention to the depiction of the mother and her reaction over the loss of her beloved son in two poems from different literary periods. The portrayal of the mother, by both poets, proves similarity despite differences in exposition. The poems are: Siegfried Sassoon's poem The Hero and Walt Whitman's poem come up from the fields father. Each poet portrays the worries and the sorrow of the mother after receiving the death letter. The paper does not depict a mother-son relationship but depicts the calamity of war focusing on the most beloved one.
\end{abstract}

Keywords: War, Mother, letter, Loss, First World War, Civil war, bereavement.

\section{INTRODUCTION}

The dilemma of war was a raw material for most poets to protest, condemn and show the reality and the losses of war. Siegfried Sassoon, the English soldier-poet, was one of those who are well remembered for his satirical realistic poems during the WWI. Prior to this war, Walt Whitman, the American poet, also witnessed the horrors and the misery caused by war in the hospitals which he served at as a volunteer during the Civil War in America 1861-1865. War poetry highlights the presentation of life and death of the soldiers in the trenches through different techniques and styles, however, few of them focused on the consequences of war upon their families, especially their mothers and the losses brought by war upon them.

\section{SASSOON THE SOLDIER-PoET}

Siegfried Lorraine Sassoon (1886-1967) is a British poet. He was the only soldier- poet to be widely read during the WWI war. He lived an easy life of a country gentleman before the WWI, with two major interests in his life, fox hunting and poetry. Sassoon first saw action in late 1915, serving with the Royal Welsh Fusiliers; the same year, he received a Military Cross for bringing back a wounded soldier during heavy fire (Bloom, 2003: 43).

His early war poetry was characterized by a spirit of celebrating the sacrifice of the young who go off to battle. This spirit declined gradually due to the horrors he experienced at the front line. Moreover, during a recovery period (after being wounded in action), and as the war went on examining the politics of war and witnessing the death of many friends, his poetic depiction turned to be more realistic, concrete, visual and his language became increasingly colloquial and bitter. This change in his poetic style was a way to release his dislike and refusal of what he witnessed in the frontlines and he turned totally to be a pacifist (Riesman, 2012: 188).

Miller confirms Sassoon's anti-war inclination as well as his rejection of the incompetence of the politicians and church men:

"Discouraged by the politics of war at home and the deaths of numerous Friends at the front, he made contact with the group of pacifists led by Bertrand Russell and Lady Ottoline Morrell. He returned to France in January 1917, was wounded by a sniper during 
a raid near Fontaine-les-Croisilles in April and was send back to England. Encouraged by Russell and the journalists John Middleton Murry and H. W. Massingham, he wrote his soldier's statement Or 'declaration against the war', dated $15^{\text {th }}$ June 1917 , calling for a negotiated Peace, and acted to resign his commission." (Miller \&Lee: n.d.)."

\section{A Study of Siegfried Sassoon's Poem "The Hero"}

During Sassoon's wartime, his ideas were changed to a realistic approach in narrating his experience. The poem "The Hero" falls into the category of poetic realism. The title contrasts the content in term of the concept of heroism. The language of this poem, in general, is communicative with clear expressions in three stanzas. Punctuation marks, effectively, manages the change of speech acts to deal with both the reality and the deceit. In this respect Puissant says:

"The situation is presented by a third person narrator, probably the dead son Watching the conversation between his mother and the officer from outside. The poem thus qualifies as a 'self-contained dramatic piece', strongly relying On the concept of dramatic irony on several layers: the speaker, the officer and The reader knows more about the real nature of the son's death than the mother; The mother and the reader, on the other hand, know more about the lies of the Politicians and war leaders" (Puissant, 2009: 137)

'Jack fell as he'd have wished', the mother said

And folded up the letter that she'd read.

'The colonel writes so nicely'. Something broke

In the tired voice that quavered to a choke.

She half looked up. 'We mothers are so proud

Of our dead soldiers.' Then her face was bowed.

The reader traces three characters in the poem; the officer, the mother and the dead son who acts as a narrator of the poem knowing the reality like the officer; who hides the grim reality from the mother by telling her a series of lies about the bravery of her son. The poem begins after reading the awful letter sent to Jack's mother when she says: "Jack fell as he'd have wished". It is the voice of the mother as she folds up the letter of Jack's death news. Then she comments on the language of the colonel pretending that she accepts her son's martyrdom as a brave woman, however, the assertive tone cannot overcome the description of her face.

"Something broke in the tired voice that quavered to a choke" the message of death put her feelings and sensations under considerable pressure; her voice trembled as if she is about to cry and her power to speak betrays her, but she regains her balance when she tries to comment in a brittle voice "she half looked up" we mothers are so proud of our dead soldiers"; she plays the role of a brave and proud mother but her body language cannot conceal the bitterness she is in. puissant shows that:

"The mother's sentence remains ambivalent as we do not know whether

She really believes what she is saying, or whether she acts as is expected

Of her by society as a patriotic and dutiful mother. Both officer and mother

Construct an image of a world that does not exist as such. It is outfaced

by front-line realities. Thus the word 'proud' describing the mother's

Attitude can easily be replaced by ' sad' "(Ibid: 137).

"Then her face was bowed." ,her facial appearance; eyes, looks, voice and the nodding of her head indicate the sense of heartbreak that started, gradually, crawling to her body. A dramatic scene where the narrator describes the gradual deterioration falls on the mother silently.

Quietly the Brother Officer went out.

$H e^{\prime} d$ told the poor old dear some gallant lies

That she would nourish all her days, no doubt

For while he coughed and mumbled, her weak eyes 
Had shone with gentle triumph, brimmed with joy,

Because he'd been so brave, her glorious boy.

The officer and the mother both play roles against the reality and the truth far in the battlefield. "Some gallant lies" is the language of the officer, who leaves the mother" the poor old dear" with such lies to rely on for the rest of her life. The contrast lies between the formality of the first stanza and the rest of the poem. While the officer tells the fallacious story of the son, the mother appears delighted with the fabricated story" Her weak eyes had shone with gentle triumph, brimmed with joy, because he'd been so brave, her glorious boy". The story acts as a tranquilizer for this old, dear lonely mother, nevertheless, her eyes still weak and dead like her soul.

\section{He thought how 'Jack', cold-footed, useless swine,}

Had panicked down the trench that night the mine

Went up at Wicked Corner. How he'd tried

To get sent home, and how, at last, he died

Blown to small bits. And no one seemed to care

Except that lonely woman with white hair.

The real story of the son is narrated in the third stanza leaving the mother alone with a slight light of her son's bravery "And no one seemed to care except the lonely woman with white hair". Loneliness, depression and old age are the harsh companions of her life, while her sweet companion died in vain. The irony lies between the second and the third stanza; the brave and the glorious boy was, in fact, a "useless swine", "panicked", "cold-footed". The poet exposes the misery of war using irony as a tool and representing the reality in the frontline and the loss of the mother at home (Puissant2009: 137). The rhyme scheme is aabbcc for the first and the third stanza while the second stanza is: ababcc, this variation suits the content of this stanza when the officer is telling lies " he coughed and mumbled" about Jack. Furthermore, the pretended stability of the mother in the first stanza and the grim fact in the third stanza render the unity of the rhyme scheme.

Finally, concrete dramatic scene that created by the poet aims at evoking the feelings of pity which overwhelm the reader with the end of the poem. Loneliness and bitterness, left to this white-haired woman, are endless. The reader could deduce that the letter brought the news of the son's death and the mother's death respectively. The title stands against the reality mentioned in the third stanza eventually, the hero of the poem is the mother who bears up the loss of her son and obliged to live on with such a lifeless body and heart.

\section{Walt Whitman AND the Civil War}

Whitman was born to a working-class family with a free-thinking that was directly affected by the economic changes occurring in America. He spent his adult years as a prolific journalist and he involved himself in city life and democratic politics. He worked for a dozen newspapers between the years of 1838 and 1850. Furthermore, he supported the Democratic Party and many democratic splinter groups joining the Free- Soil Party, then finding and publishing a Free-Soil paper (Casale, 2010:43).

Whitman's war poetry deals with his experience during the civil war $(1861-1865)$. He was a volunteer in Washington's hospitals in 1863. A family duty was the reason of being a volunteer; on December 1862, a newspaper published a list of wounded soldiers with a misspelled name of Whitman's brother that urged him to move to that place to see his brother. After that, he decided to stay close to the war and seek an employment in Washington. In this respect, Killingsworth says:

Within days of moving to Washington, the poet realized his

Truest war time vocation as he began to make visits to the

Wounded and dying in the war hospitals. Moved by the bravery

And personal beauty of those young men, mostly uneducated boys

From the farms and towns of America, Whitman became something 
Of an institution in the hospitals. He brought refreshments for the

Soldiers, read the bible for them or whatever they requested, wrote

Letters home on their behalf (and wrote to them once they returned

To the front or to home), stood by during some fearsome medical

Treatments, and sat many a death watch as gangrene or illness wore

Away at the unlucky ones (Killingsworth: 9).

He used to write to his friends and his mother about the horrible appalling things; deaths, operations, sickening wounds that he watches in the hospital. Meanwhile, this place was a fertile ground for Whitman to write as a release of his stress; he wrote dozens of newspaper articles, poems, essays, books an outcome of his work as a volunteer in the hospitals. He worked on a series of poems during this period with evocative titles like, Drum Taps. Later on, he told Horace Traubel that Drum Taps had been put together by fits and starts, on the fields, in the hospitals, as he worked with the soldier boys (Morris, 2000:144). This short book of poetry on the war was entitled Drum-Taps; first published as an independent book in 1865, and then incorporated as a cluster in Leaves of Grass. Drum -Taps is one of the best poetry the war produced (killingsworth, 2007: 10).

\section{A Study OF Whitman's Poem "COMe UP From the Fields Father"}

The poem is written in free verse with variable line length. The poem is ungoverned by rhyme or meter; but manipulates Punctuation marks suggesting a kind of pause to visualize the scene wholly, and to deal with the recounting of the imagined battlefield narrator in repetitive poetic structures. The analysis of the poem deals with the description of the mother in a dramatic scene consisting of: the letter, the family, the nature and the mother. The title contains the name "father" while there is no role or reference to the father in the whole poem. The style is dramatic where the poet plays the role of an imagined battlefield narrator and the mode of the poem is elegiac. Killings worth explains the modes of Whitman's poetry:

"The elegiac mode appears in wartime poems explicitly dealing with

The death of comrades (real or imagined). The mode proves dominant

In Drum-Taps poems ( killingsworth, 2007: 58).

The poem begins with a call of the daughter announcing the arrival of her brother's letter" Come up from the fields, father, here is a letter from our Pete, and come to the front door mother, here is a letter from thy dear son".

The letter will be the trigger for the psychological trauma of the mother. From this line, the narrator directs the reader's attention to the portrayal of nature in Ohio farms:

"Lo, 'tis autumn, Lo, where the trees, deeper green, yellower and redder, cool and sweeten Ohio's villages with leaves fluttering in the moderate wind,

Where apples ripe in the orchards hang and grapes on the trellis'd vines,

(Smell you the smell of the grapes on the vines?

Smell you the buckwheat where the bees where lately buzzing?)

Above all, Lo, the sky, the sky so calm, so transparent after the rain,

And with wondrous clouds,

Below too, all calm, all vital and beautiful, and the farm prosper well.

Down in the fields all prospers well,"

The description of nature begins with anaphora (repetition of beginnings); "Lo, 'tis autumn", " Lo, where the trees". "Lo" is also an interjection, where the poet expresses wonders or surprise over a specific scene. Repetition of "smell" strengthens the perception of the odor, and repetition of "all" suggests unity and harmony. Repeated words, phrases and photographic terms enhance the sense imagery in the reader's mind as well as developing the idea that Whitman intends to propose concerning connotations of autumn. Gross clarifies Whitman's poetic language: 
"The most important single device in Whitman's prosody is syntactical

Parallelism such as anaphora or enumeration, where the parallel structures

Involve grammatical and logical ellipses, as in incomplete sentences, lines

Not related to each other." (qtd in Mazur,2005: 136).

Besides, the depiction of autumn is conveyed in its most beautiful forms of colors contributed to the portrayal of the season; the space of nature is wide, warm, tranquil and colorful. In this respect, it is important to deal with Whitman's philosophy considering nature: "He believed that the physical world is the embodiment of spirit and that the human soul urgently seeks connection with this spiritual reality" (Abbott, 1996: 350).

Killingsworth (2007:610) asserts that in the elegiac poems of Drum-Taps, Whitman insisted on the survival of the soul after death. Additionly, autumn stands for the meaning death as Ferber asserts:

"Some of the most delicate and convincing of modern descriptions of

The season hold both facets of autumn in balance, the fullness and

Satisfaction of the harvest with the coming on of winter and death." (Ferber, 2007:17)

The ominous silence of the season predicts the coming of death and the calamity awaiting this family, specifically, the mother. It is the season of harvesting the apples and grapes, parallel to the harvesting of souls in war. The beauty of the harvest season opposes the ugliness of war approaching this family.

"But now from the fields come father, come at the daughter's call, and come to the entry mother, to the front door come right away". The tragedy begins from the moment when the mother got rattled when she heard her son's name. The physiological disturbance, she is in, affects her behavior " " fast as she can she hurries, something ominous, her steps trembling, she does not tarry to smooth her hair nor adjust her cap". She opens the envelope quickly; she realizes that it is not her son's handwriting, although his name is signed. The poetic apostrophe for this description calls attention to the range of emotions, surprise and sorrow joined with the opening of the envelope.

"Open the envelope quickly, $\boldsymbol{O}$ this not our son's writing, yet his name is signed, $\boldsymbol{O}$ a strange hand write for our dear son, $\boldsymbol{O}$ stricken mother's soul!" . the narrator of this dramatic scene describes the mother as she reads the letter " all swims before her eyes, flashes with black, she catches the main words only,"; her eyes are filled with tears that is why she cannot mark the words vividly, however, the bitter reality in the letter flashes with black color. The " $\mathrm{O}$ " is used in poetic apostrophe to suggest a range of emotions; here in this poem, the mother's emotions vary between hesitation, sorrow, pain, and fear. Even the clauses reflect the hasty looks of the mother due to her fear and panic. Her eyes catches only the main words " sentences broken, gunshot wound in the breast, cavalry skirmish, taken to hospital, at present low, but will soon be better." The narrator is reading the letter through her eyes; his eyes are hers, no difference. It is the poet's skill and ability to attain the mother's senses and eyes in a way adequate to the eagerness of a mother in reading a letter about her son. The phrases appear in the same manner that the mother's eyes catch the news of her son's injury.

The narrator, now, shifts his attention "Ah now the single figure to me, amid all teeming and wealthy Ohio with all its cities and farms" to one single figure, the mother, who "sickly white in the face and dull in the head, very faint, by the jamb of a door leans." The description evokes a deadly figure that is still waiting. Spirituality and mentality, she is neither live nor dead. The rest of the poem is devoted to "The single figure to me", meanwhile, the gathering of her daughters cannot soothe or decrease her pain " Grieve not so, dear mother, (the just-grown daughter speaks through her sobs, the little sisters huddle around speechless and dismay'd,) see, dearest mother, the letter says Pete will soon be better." Pete's sisters also know that their mother is right in her dismay and bitterness and they try vainly to console their mother. Listening to the poet, the imagined narrator or the observer confirms the truth that Pete id dead already, "Alas poor boy, he will never be better, (nor may-be needs to be better, that brave and simple soul,). The repetitions of "be better" whether to the son or the mother suggest the spiritual bond between them that needs healing.

While they stand at home at the door he is dead already, the only son is dead. Repetitive lines are for emphasizing the feeling of loss since the theme of the poem is the toll of war. So, the narrator, who 
gives a detailed account of the whole scene, announces and knows that the son is dead from the moment they received the letter; amazingly, the mother's reaction and her ominous sense does not come wrong with the reality of war.

The son is dead now, while the mother is still alive, biologically, and should be better" but the mother needs to be better," " she with thin form presently drest in black". The observer describes the mother as "figure" and "form" twice; he ascribes the qualities of a dead object rather than a living one. The daily description given for this dead mother is awful. Gradually she withdraws herself from life and all the practices of life " By day her meals untouch'd, then at night fitfully sleeping, often waking, in the midnight waking, weeping, longing, with one deep longing, ". The use of the -ing ending evokes continuity and long action " sleeping", "waking", "waking", " weeping", "longing", "longing"; the repetition of the verbs " waking" and " longing" connote the sense of deprivation of life from her daily actions. It also connotes the continuity of the thoughts of loss, pain, sorrow, bitterness crawling slowly to her soul day by night.

Retreating from life silently, the mother embraces death in the same sense of silence that she accepted unwillingly her son's death "oh that she might withdraw unnoticed, silent from life escape and withdraw,

To follow, to seek, to be, with her dear dead son." The mother- son relationship is unbreakable even by death. The letter brought death to both of them whether in frontline or in Ohio's farms. The poem ends also with anaphora; "to follow", "to seek", "to be with her dead son". It is an emphasis on the mother's need to join her son. She is totally estranged from life waiting for death as the only means to be with her son.

\section{CONCLusion}

Regardless of their literary periods, the poems could be read as dramatic scenes. In both poems, the depiction of the bereavement of the mothers is the same, although the poetic language of the poets is different. The letter acts as an ill omen or a death invitation for the mothers who accept it quietly. In both poems, the mother is the hero who endures the pain and the shock as she is obliged to bear up her life with a burden imposed by war, and never being appreciated by the society. There is no celebration of the soldiers' sacrifice but rather representing the other side of war that is the families, and showing that death lies not in the trenches, but also brought to home to their beloved ones. The mothers leave much unsaid about their son's loss, meanwhile the sense of mourning and bereavement is prevailing. War is forced upon the mother and the psychological cost is unbearable. The reader is overwhelmed by feeling of pity for the suffering of the mother more than the son due to the artistic skills of both Sassoon and Whitman.

\section{REFERENCES}

[1] Bloom, Harold. Comprehensive Research and Study Guide. Poets of World War I, Rupert Brooke and Siegfried Sassoon, Bloom's Major Poets. (2003). USA.

[2] Reisman, Rosemary M. Canfield. Critical Survey of Poetry, War Poets. Charleston Southern University. Salem Press, a Division of EBSCO Publishing, Ipswich, Massachusetts. (2012).

[3] Miller, A. and Lee, S. (n.d.) The First World War poetry. Digital Archive. The Siegfried Sassoon collection. Retrieved from http://WWIlit. Nsms.ox.ac.uk/ wwIlit/collections/Sassoon.

[4] Puissant, Susanne Christine. Irony and the Poetry of the World War. Palgrave Macmillan. Great Britain. (2009).

[5] Casale, D. Frank. Blooms How To Write about Walt Whitman. Introduction by Harold Bloom. Infobase Bublishing . New York.(2010).

[6] Killingsworth, M. Jimmie. The Cambridge Introduction to Walt Whitman. Cambridge university press. UK. (2007).

[7] Mazur, Krystyna. Poetry and Repetition. Walt Whitman, Wallace Stevens, John Ashbery. Rout ledge Taylor. Great Britain. (2005).

[8] Abbot, Ahearn, and Judith Austin-Mills, eds. Adventures in American Literature. USA. (1996).

[9] Morris Roy, Jr. The Better Angel: Walt Whitman in the Civil war. Oxford University press.(2000).

[10] Ferber, Michael. A Dictionary of literary Symbols. $2^{\text {nd }}$ edition. Cambridge University press. USA. (2007). 
AUTHOR'S BIOGRAPHY

Dr. Kanar Asaad Adham, PH.D in English Literature. She graduated from the College of Arts- English Department- university of Al- Mustansrya- Baghdad, 19911992. She is one of the staff members of the English Department- College of Languages- University of Sulaimani since 2004. Her major field of interest in English Literature is Victorian Age, Elizabethan Age and Modern poetry. 